\title{
Identification of a Chlorovirus PBCV-1 Protein Involved in Degrading the Host Cell Wall during Virus Infection
}

\author{
Irina V. Agarkova ${ }^{1,2, *}$, Leslie C. Lane ${ }^{2}$, David D. Dunigan ${ }^{1,2}\left(\right.$, Cristian F. Quispe ${ }^{1,2}$, Garry A. Duncan ${ }^{1}{ }^{\circledR}$, \\ Elad Milrot $^{3}$, Abraham Minsky ${ }^{3}$, Ahmed Esmael ${ }^{4}{ }^{\circledR}$, Jayadri S. Ghosh ${ }^{1,2}$ and James L. Van Etten ${ }^{1,2, *(1)}$ \\ 1 Nebraska Center for Virology, University of Nebraska-Lincoln, Lincoln, NE 68583-0900, USA; \\ ddunigan2@unl.edu (D.D.D.); quispecristian@gmail.com (C.F.Q.); gduncan@nebrwesleyan.edu (G.A.D.); \\ jghosh2@unl.edu (J.S.G.) \\ 2 Department of Plant Pathology, University of Nebraska-Lincoln, Lincoln, NE 68583-0722, USA; \\ lclane2@gmail.com \\ 3 Department of Structural Biology, The Weizmann Institute of Science, Rehovot 76100, Israel; \\ eladm@iibr.gov.il (E.M.); avi.minsky@weizmann.ac.il (A.M.) \\ 4 Botany and Microbiology Department, Faculty of Science, Benha University, Qalubiya Governorate, \\ Banha 13511, Egypt; a7medesmael@gmail.com \\ * Correspondence: irina@unl.edu (I.V.A.); jvanetten1@unl.edu (J.L.V.E.); Tel.: +1-402-472-3168 (J.L.V.E.)
}

check for

Citation: Agarkova, I.V.; Lane, L.C.; Dunigan, D.D.; Quispe, C.F.; Duncan, G.A.; Milrot, E.; Minsky, A.; Esmael,

A.; Ghosh, J.S.; Van Etten, J.L.

Identification of a Chlorovirus PBCV-1 Protein Involved in

Degrading the Host Cell Wall during Virus Infection. Viruses 2021, 13, 782. https://doi.org/10.3390/v13050782

Academic Editor: Jozef Nissimov

Received: 7 April 2021

Accepted: 26 April 2021

Published: 28 April 2021

Publisher's Note: MDPI stays neutral with regard to jurisdictional claims in published maps and institutional affiliations.

Copyright: (C) 2021 by the authors. Licensee MDPI, Basel, Switzerland. This article is an open access article distributed under the terms and conditions of the Creative Commons Attribution (CC BY) license (https:/ / creativecommons.org/licenses/by/ $4.0 /)$.

\begin{abstract}
Chloroviruses are unusual among viruses infecting eukaryotic organisms in that they must, like bacteriophages, penetrate a rigid cell wall to initiate infection. Chlorovirus PBCV-1 infects its host, Chlorella variabilis NC64A by specifically binding to and degrading the cell wall of the host at the point of contact by a virus-packaged enzyme(s). However, PBCV-1 does not use any of the five previously characterized virus-encoded polysaccharide degrading enzymes to digest the Chlorella host cell wall during virus entry because none of the enzymes are packaged in the virion. A search for another PBCV-1-encoded and virion-associated protein identified protein A561L. The fourth domain of A561L is a 242 amino acid C-terminal domain, named A561L ${ }^{\mathrm{D} 4}$, with cell wall degrading activity. An A561L $\mathrm{L}^{\mathrm{D}}$ homolog was present in all 52 genomically sequenced chloroviruses, infecting four different algal hosts. A561L ${ }^{\mathrm{D} 4}$ degraded the cell walls of all four chlorovirus hosts, as well as several non-host Chlorella spp. Thus, A561L ${ }^{\mathrm{D} 4}$ was not cell-type specific. Finally, we discovered that exposure of highly purified PBCV-1 virions to A561L ${ }^{\mathrm{D} 4}$ increased the specific infectivity of PBCV-1 from about $25-30 \%$ of the particles forming plaques to almost $50 \%$. We attribute this increase to removal of residual host receptor that attached to newly replicated viruses in the cell lysates.
\end{abstract}

Keywords: Chlorella; Phycodnaviridae; chlorovirus; PBCV-1; algal lytic activity; cell wall degrading activity; alginate-like lyase

\section{Introduction}

A major difference between viruses that infect bacteria and eukaryotic organisms is the initial events associated with infection. Typically, bacteriophages are confronted with the problem of binding to and penetrating a bacterial cell wall (the wall is often referred to as the outer membrane or outer cell envelope) in order to eject their genome into the interior of the cell. Penetration of the bacterial wall typically involves a virus-packaged wall digesting enzyme(s), often referred to as a peptidoglycan hydrolase or endolysin [1], frequently located in a tail structure of tailed phages. The ejection of phage DNA into the cell usually results in an empty virus capsid remaining on the outside of the cell. In contrast to bacteriophages, viruses that infect animal cells only have to deal with a plasma membrane, and after attachment to the membrane, typically the entire nucleocapsid particle is taken into the cell either by endocytosis or phagocytosis, or by membrane fusion [2]. Therefore, un-coating of the viral genome typically occurs inside the host cell or at the plasma membrane. Viruses that infect higher plants also have to deal with cell walls but 
they avoid the issue by either infecting wounded cells (mechanical infection) or a biological vector transfers the particles to the inside of the plant cell and the viruses subsequently move cell-to-cell via plasmodesmata.

The large icosahedral, plaque forming, dsDNA chloroviruses (family Phycodnaviridae, genus Chlorovirus) are unusual among viruses infecting eukaryotic organisms in that they, like bacteriophages, need to penetrate a rigid algal cell wall to initiate infection. They infect freshwater, unicellular, eukaryotic green algae, which normally exist as mutualistic endosymbionts in protists and are often referred to as zoochlorellae. Chloroviruses fall into four clades based on their hosts [3]. NC64A viruses infect Chlorella variabilis NC64A [4,5], Osy viruses infect Chlorella variabilis Syngen 2-3 [6], SAG viruses infect Chlorella heliozoae [4] and Pbi viruses infect Micractinium conductrix [7].

The prototype Chlorovirus Paramecium bursaria chlorella virus (PBCV-1) is an icosahedron (190 nm in diameter) with a spike structure at one vertex [8], which appears to make the first contact with the cell wall of its host, C. variabilis NC64A [9]. Attachment is immediately followed by cell wall degradation precisely at the point of contact by a virus-packaged enzyme(s) [10]. Following wall degradation the viral internal membrane fuses with the host membrane [11] causing immediate host membrane depolarization [12] and potassium ion efflux [13]. These events lower the turgor pressure of the host and facilitate entry of the viral DNA and virion-associated proteins into the cell [14], leaving an empty viral capsid on the cell surface [10]. Therefore, the initial infection process or un-coating of the genome is similar to that of many bacteriophages.

Degradation of the $C$. variabilis NC64A wall is associated with two events in the PBCV1 life cycle. Besides entry into the cell, nascent infectious viruses exit the cells at 6 to $8 \mathrm{~h}$ post infection (PI) by cell lysis [15]. It is not known if chloroviruses use the same set of enzymes for both events. The $331 \mathrm{~kb}$ linear PBCV-1 genome has 416 putative protein coding sequences (CDSs) [16]. About 50\% of these CDSs resemble known proteins including two chitinases [17,18], a chitosanase [18,19], a $\beta-1,3$ gluconase [20], and a polysaccharide lyase, cleaving chains of $\beta$ - or $\alpha-1,4$-linked glucouronic acids [21,22], hereafter referred to as vAL-1. Recombinant proteins have been produced from each of these five genes and shown to have the predicted polysaccharide degrading enzyme activity [23].

Furthermore, previous experiments indicate that a crude enzyme preparation made from PBCV-1 lysates, named wLysin (wall Lysin as compared to virion isolated, vLysin), has good wall degrading activity and can lead to C. variabilis NC64A protoplast formation [24,25]. Therefore, it was assumed that one or more of these five PBCV-1-encoded enzymes were packaged in the PBCV-1 virion and were responsible for degrading the host cell wall at the point of infection. In fact, a chitosanase was reported to be packaged in the virion of a closely related chlorovirus, CVK2 [19]. However, a subsequent report [17] indicated that the chitosanase activity associated with the CVK2 particles was due to incomplete purification of the virion. Subsequently, a PBCV-1 proteomic study of highly purified virions identified 148 virus-encoded proteins and one host encoded protein [16]. Unexpectedly, however, none of the five polysaccharide-degrading enzymes are packaged in the PBCV-1 virion.

In this report, we have re-examined the 148 virus-encoded proteins that are packaged in the PBCV-1 virions for possible polysaccharide or cell wall degrading activity. The result was that a putative polysaccharide hydrolase domain was identified in one of the PBCV-1 encoded proteins packaged in the virion, CDS A561L (GenBank https: / www. ncbi.nlm.nih.gov/protein/9632119, gene ID: 917870, accession no. NP_048917). Therefore, we tested the hypothesis that $\mathrm{A} 561 \mathrm{~L}$ is involved in the digestion of the cell wall at the point of viral attachment.

\section{Materials and Methods}

\subsection{Viruses and Host Strains}

The virus PBCV-1 host $C$. variabilis NC64A was grown in modified Bold's basal medium (MBBM) [26]. All other green algae were also grown in MBBM with some ex- 
ceptions: C. variabilis NIES 2540 and C. variabilis NIES 2541 were grown in MBBM supplemented with 1mL/L 1\% thiamin; M. conductrix Pbi was grown in FES medium [27]. PBCV-1 virus production, ultra-purification and plaque assay of viruses was carried out as described previously $[26,28,29]$.

\subsection{Recombinant $A 561 L$ and $A 561 L^{D 4}$}

For protein overexpression the Champion pET Directional TOPO cloning kit was employed (Thermofisher Scientific, Waltham, MA, USA). PBCV-1 open reading frame $A 561 \mathrm{~L}$ and truncated $A 561 \mathrm{~L}^{D 4}$ encoding the 247 amino acid C-terminal region of A561L were cloned from PCR-amplified viral DNA. The primers were designed to generate compatible overhangs following the pET 102/DTOPO plasmid kit guidelines (Thermofisher Scientific, Waltham, MA, USA). Cloned DNA fragments were verified by sequencing. Plasmids were multiplied using One Shot ${ }^{\circledR}$ TOP10 chemically competent $E$. coli and were conserved at $-80{ }^{\circ} \mathrm{C}$ in $20 \%$ glycerol stocks.

Recombinant proteins were expressed in BL21 Star (DE3) E. coli, using $0.5 \mathrm{mM}$ IPTG following the pET102/DTOPO kit guidelines and the Ni-NTA agarose affinity chromatography matrix for purifying recombinant proteins carrying a His tag. The soluble protein size was approximately $42 \mathrm{kDa}$ with the His-Patch thioredoxin tag (provides an efficient fusion partner for translation of the fusion protein), V5 epitope tag (for detection of the fusion protein by the anti-V5 antibodies) and $6 \mathrm{xHis}$ tag.

\section{3. vLysin Preparation and Activity Assay}

A PBCV-1 virus preparation $(4 \mathrm{mg} / \mathrm{mL})$ in $\mathrm{TB},(50 \mathrm{mM}$ Tris $\mathrm{HCl}, \mathrm{pH} 7.8)$ was mixed with an equal volume of lysing solution [50 mM KOH, $100 \mathrm{mM}$ MOPS (pH 7.0), $10 \mathrm{M} \mathrm{LiCl}$, $4 \mathrm{mM} \mathrm{Na} 2 \mathrm{EGTA}$ ], incubated for $50 \mathrm{~min}$ at $37^{\circ} \mathrm{C}$ then spun for $20 \mathrm{~min}$ at $21,000 \times g$ and the supernatant fraction was collected. The supernatant fraction containing vLysin, was dialyzed for $24 \mathrm{~h}$ at $4{ }^{\circ} \mathrm{C}$ against 3 changes of $25 \mathrm{mM} \mathrm{KOH}, 50 \mathrm{mM}$ MOPS (pH 7.0).

\subsection{Cell Wall Degrading Activity Assayed by Chlorophyll Release}

The assay measured chlorophyll release as a result of cell wall digestion of the algae [30]. Chlorella cells were freshly harvested from 4-day-old cultures $\left(1.0-1.5 \times 10^{7}\right.$ cells $\left./ \mathrm{mL}\right)$ by centrifugation at $4000 \times g$ for $3 \mathrm{~min}$, washed one time with sterile TB and then re-suspended in TB at a concentration of $2.5 \times 10^{7}$ cells $/ \mathrm{mL}$. Unless otherwise indicated, lysis activity was determined in $100-\mu \mathrm{L}$ reaction mixtures in $\mathrm{TB}$ supplemented with $10 \mathrm{mM} \mathrm{CaCl} 2$ using $C$. variabilis NC64A cells at a concentration of $2.5 \times 10^{7} / \mathrm{mL}$ with specified amounts of A561L ${ }^{\mathrm{D}}$ followed by incubation for $1 \mathrm{~h}$ at room temperature. To facilitate chlorella cell wall rupture by the protein, SDS was added to $1 \%$ concentration (final) and incubated for $1 \mathrm{~min}$ at room temperature, then centrifuged for $15 \mathrm{~min}$ at $16,000 \times \mathrm{g}$. The optical densities of the supernatant fractions were determined in a Beckman DU 530 UV/Vis spectrophotometer (Beckman-Coulter, Indianapolis, IN, USA) at a $\lambda$ of $420 \mathrm{~nm}$. The amount of detected chlorophyll served as an indicator of the extent of cell wall degradation by the recombinant protein.

The determination of optimal temperature for $\mathrm{A} 561 \mathrm{~L}^{\mathrm{D} 4}$ was performed at $10^{\circ} \mathrm{C}$, $15^{\circ} \mathrm{C}, 20^{\circ} \mathrm{C}, 25^{\circ} \mathrm{C}, 30^{\circ} \mathrm{C}, 37^{\circ} \mathrm{C}, 45^{\circ} \mathrm{C}, 50{ }^{\circ} \mathrm{C}, 55^{\circ} \mathrm{C}$ and $60^{\circ} \mathrm{C}$ with $10 \mu \mathrm{g} / \mathrm{mL}$ A561L $\mathrm{L}^{\mathrm{D} 4}$ concentration. To evaluate an optimal $\mathrm{pH}$ for lysing activity an array of $100 \mathrm{mM}$ Tris-citrate buffers ranging in $\mathrm{pH}$ from 2.4 to 9 was used. Divalent-cation experiments were performed in the same reaction mixture by replacing $\mathrm{CaCl}_{2}$, with $10 \mathrm{mM} \mathrm{MgCl}_{2}, \mathrm{MnCl}_{2}, \mathrm{CuCl}_{2}, \mathrm{CoCl}_{2}$, $\mathrm{FeSO}_{4}, \mathrm{ZnSO}_{4}, \mathrm{NiCl}_{2}$, EDTA or EGTA.

\subsection{Protein Activity Assayed by Calcofluor-White (CFW) Release}

The preparation of $C$. variabilis NC64A ghost cells has been described elsewhere [25]. Briefly chlorella cells at a concentration of $1-1.5 \times 10^{7}$ cells $/ \mathrm{mL}$, were harvested and extracted multiple times with methanol until the chlorophyll was removed. To remove traces of methanol, the ghost cells were washed three times with TB before an experiment. Chlorella ghost cells at $5 \times 10^{7}$ were stained with $0.001 \%$ (final concentration) CFW for 
$30 \mathrm{~min}$, then washed 4 times with TB and re-suspended in TB. Cell wall degrading activity was determined in a $100 \mu \mathrm{L}$ reaction mixture in TB containing $4 \times 10^{6}$ (total) chlorella ghost cells and the indicated amount of protein. After $1 \mathrm{~h}$ incubation at room temperature the reaction mixture was spun at $16,000 \times g$ for $15 \mathrm{~min}$, the supernatant fraction was removed and released CFW was measured in a Beckman DU $530 \mathrm{UV} /$ Vis spectrophotometer at $\lambda=215 \mathrm{~nm}$.

\subsection{Effect of A561L ${ }^{D 4}$ Protein Treatment of C. variabilis Ghost Cells on PBCV-1 Virus Attachment}

Ghost cells $\left(10^{8}\right.$ cells $\left./ \mathrm{mL}\right)$ in TB with $10 \mathrm{mM} \mathrm{CaCl}_{2}$ were treated with various amounts of $\mathrm{A} 561 \mathrm{~L}^{\mathrm{D} 4}$ at room temperature. After $1 \mathrm{~h}$ of incubation of ghost cells, the reaction was spun for $30 \mathrm{~s}$ at $16,000 \times g$, the supernatant fraction was collected for future experiments and pelleted ghost cells were washed with TB one time, then re-suspended in $200 \mu \mathrm{L}$ of TB with $10 \mathrm{mM} \mathrm{CaCl}_{2}$.

PBCV-1 virus was added to the treated ghost cells at a MOI of 10 and incubated at room temperature. The control was virus incubated in $\mathrm{TB}$ with $10 \mathrm{mM} \mathrm{CaCl}_{2}$. After $1 \mathrm{~h}$ incubation, serial dilutions of the reactions were made and virus infectivity was plaque assayed.

\subsection{Effect of Soluble Products (Possibly Receptors) Resulting from A561L ${ }^{D 4}$ Treatment of C. variabilis NC64A Ghost Cells on PBCV-1 Virus Infectivity}

NC64A ghost cells $\left(10^{8}\right.$ cells $\left./ \mathrm{mL}\right)$ in TB with $10 \mathrm{mM} \mathrm{CaCl} 2$ were treated with different amounts of recombinant $\mathrm{A} 561 \mathrm{~L}^{\mathrm{D} 4}$. After incubation for $1 \mathrm{~h}$ at room temperature, treated ghost cells were spun for $15 \mathrm{~min}$ at $16,000 \times g$ and the supernatant fractions were collected. PBCV-1 virus was added to the collected supernatant fractions at a concentration of $10^{9} \mathrm{PFU} / \mathrm{mL}$ and incubated for $1 \mathrm{~h}$. Serial dilutions of the reactions were made and virus infectivity was plaque assayed.

\subsection{Electron Microscopy}

C. variabilis NC64A cells $\left(5-6 \times 10^{7}\right.$ cells $\left./ \mathrm{mL}\right)$ were treated at room temperature with $250 \mu \mathrm{g} / \mathrm{mL}$ recombinant A561L $\mathrm{L}^{\mathrm{D}}$ protein for $10 \mathrm{~min}$ and then concentrated by centrifugation. The electron microscopy studies of the cell wall digesting protein were carried out as described elsewhere [31]. Briefly, NC64A cells were fixed with $2 \%$ of glutaraldehyde for $2 \mathrm{~h}$ at room temperature. Then, cells were centrifuged and resulted pellets were embedded in 3.4\% agar (Difco). The pellets were trimmed and stained with $1 \% v / v$ of osmium tetraoxide in $0.1 \mathrm{M}$ cacodylate buffer at room temperature. Then, samples were washed with distilled deionized water and stained with $2 \%$ water solution of uranyl acetate. Cells were dehydrated in graded ethanol concentrations, and subsequently embedded in Eppon. Thin sections $(70-100 \mathrm{~nm}$ ) were cut by Ultracut UCT microtome (Leica) and post stained with $2 \%$ uranyl acetate and Reynold's lead citrate. Images were obtained using FEI Spirit TEM operated at $120 \mathrm{kV}$ and recorded on a CCD camera (Eindhoven, the Netherlands).

\subsection{SDS-PAGE and Western Blots}

PBCV-1 virion proteins were solubilized and separated by sodium dodecyl sulfatepolyacrylamide gel electrophoresis (SDS PAGE) as described elsewhere [32]. Resolved protein gels were either stained with Coomassie brilliant blue R-250 or transferred to a nitrocellulose membrane and hybridized with PBCV-1 A561L ${ }^{\mathrm{D} 4}$ antiserum produced in mice (dilution 1:500). Goat produced anti-mouse IgG conjugated to horseradish peroxidase (ThermoFisher Scientific, Waltham, MA, USA) was used as the secondary antibody (dilution 1:1000). SuperSignal West Pico PLUS Chemiluminescent Substrate was used for visualization (ThermoFisher Scientific, Waltham, MA, USA).

\subsection{Effect of Anti A561L ${ }^{D 4}$ Antibody on vLysin Activity}

PBCV-1 vLysin isolated from ultra-purified virions was treated with anti A561L ${ }^{\text {D4 }}$ antibody $(\mathrm{AB})$ produced in mice (800-fold dilution). After $1 \mathrm{~h}$ incubation, to remove vLysin 
neutralized with anti-A561L $\mathrm{L}^{\mathrm{D}}$ antibodies from the reaction, magnetic beads (MB) coupled with anti-mouse Ig (RayBiotech, GA, USA, cat \# 801-103) were added to the reaction and the supernatant fraction was separated from the MB following the manufacturer's instructions. The resultant supernatant fraction that presumably had vLysin activity neutralized and removed was mixed with NC64A cells at concentration $6 \times 10^{7}$ cells $/ \mathrm{mL}$ and incubated for $1 \mathrm{~h}$. SDS was added to the treated cells to $1 \%$ concentration (final) and incubated for $1 \mathrm{~min}$ at room temperature, then NC64A cells were centrifuged for $15 \mathrm{~min}$ at $16,000 \times g$, the supernatant fraction was removed and chlorophyll release was measured using a spectrophotometer (Beckman DU 530) at $\lambda=420$. Untreated PBCV-1 vLysin was used as a positive control. NC64A cells treated with pre-bleed serum and 1\% SDS served as a negative control.

\subsection{Phylogenetic Analyses}

A summary of the 52 homologs of $\mathrm{A} 561 \mathrm{~L}^{\mathrm{D} 4}$ protein analyzed in this study are provided in Supplementary Table S1. Based on these sequences multiple-sequence alignments were created using the ClustalW alignment with the Geneious 11.0.5 program (Biomatters Ltd., Auckland, New Zealand, https:/ /www.geneious.com, accessed on 27 April 2021), and the phylogenetic tree was constructed with Geneious plugin program PhyML 3.3.20180621 (Maximum likelihood) [33] using the default settings. To identify domains of the protein A561L, encoded by gene $a 561 l$, fragments of different lengths were used as queries in BLASTp searches [34] against a data base of proteins in UniProt [35] with scoring matrix BLOSUM62.

A 3D structure model of A561 $\mathrm{L}^{\mathrm{D} 4}$ domain was constructed using normal mode of the Phyre2 Server (Protein Homology/analogY Recognition Engine V 2.0) [36]. Phyre2 results were visualized and edited using VMD molecular graphics viewer software [37].

\section{Results and Discussion}

\subsection{PBCV-1 A561L Is a Candidate for Degrading the Host Cell Wall}

As noted in the introduction, PBCV-1 encodes five enzymes [23] that either alone or in combination were candidates for the presumed enzyme activity that degrades the host cell wall during the initial phase of virus infection. However, none of these proteins were detected in the virion proteome study [16].

Therefore, another bioinformatics search of the 148 PBCV-1-encoded, virus-packaged CDSs was conducted to determine if any of them might be candidates for degrading the host cell wall. The 649 amino acid A561L CDS became a candidate because its C-terminal 242 amino acid domain has $32 \%$ and 50\% amino acid identity and similarity, respectively, over 211 amino acid residues with the C-terminal portion of CDS A215L (Figure 1A). A215L is one of the previously characterized PBCV-1 polysaccharide degrading enzymes, referred to as vAL-1 [38].

In silico protein structure model of $\mathrm{A} 561 \mathrm{~L}^{\mathrm{D} 4}$ protein by Phyre2 analysis identified alginate lyase based on $86.8 \%$ coverage with $100 \%$ confidence (Table A1) from multiple available protein structures derived from the protein data bank (PDB). A crystal structure of the marine PL-14 alginate lyase from Aplysia kurodai served as a model (Figure A1 of Appendix A).

A561L has three additional domains (Figure 1B): (i) a 69 amino acid domain 1 is a transmembrane domain and has some resemblance to a transporter protein, (ii) a 241 amino acid domain 2 resembles a TolA protein and (iii) a 97 amino acid domain 3 is similar to a LEA 2 domain-containing protein (late embryogenesis abundant protein) that is nearly identical to the PBCV-1 A565R CDS (Figure A2 of Appendix A). Thus, the A561L CDS became the focus of this study. 
A

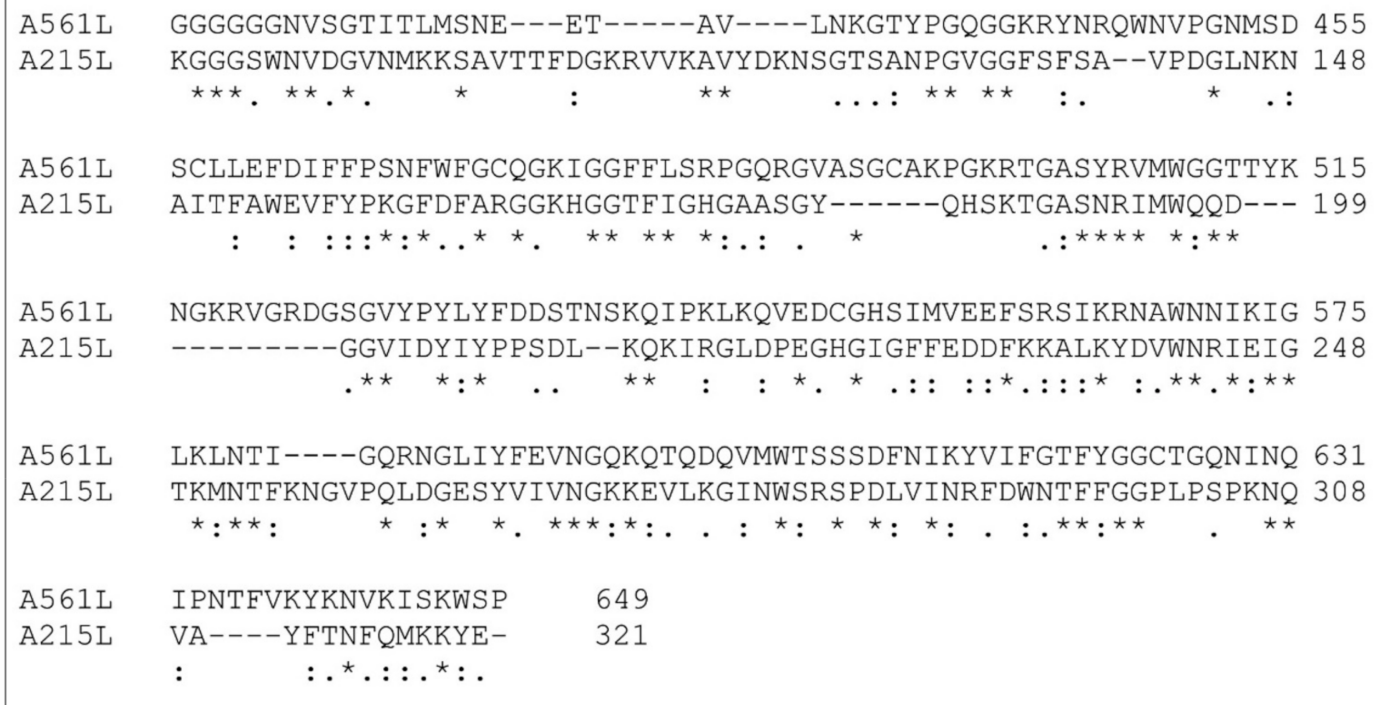

\section{B}

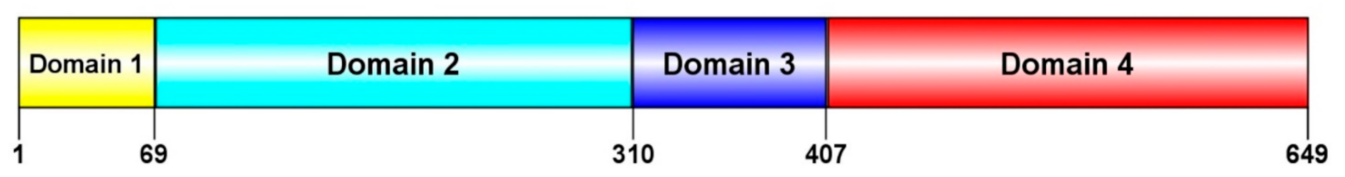

Figure 1. A561L protein characteristics: domains and possible functions: (A) Amino acid sequence pairwise alignment of a carboxyl-terminal domain of CDS A561L with the carboxyl terminus of CDS A215L; A215L was previously characterized as a polysaccharide lyase [vAL-1 protein] [38]. (B) Predicted domains in A561L-domain 4 is the part of the protein that resembles A215L (domains were identified using InterPro domain prediction database [39] with manual curation). Domain 1 has a transmembrane domain and the closest match is a transporter protein encoded by Listeria kieliensis although the E-value was low, $3.6 \times 10^{-1}$; Domain 2 has the best hit to a TolA protein of Trichomonas vaginalis (Tol proteins are involved in the stability of the outer membrane in Gram-negative bacteria) with an E-value of $4.1 \times 10^{-14}$ but it also resembles a peptidase S8 domain-containing protein from Tetradesmus obliquus with an E-value of $9.3 \times 10^{-8}$; Domain 3 resembles a LEA 2 domain-containing protein (late embryogenesis abundant protein, which plays a role in abiotic stress response and tolerance in plants and are part of the hypersensitive response to plant pathogen infection) encoded by Selaginella moellendorffii with an E-value of $6.9 \times 10^{-6}$; and Domain 4 resembles an alkaline alginate lyase/1-4 polyglucuronic acid lyase/polysaccharide lyase family 14 with an E-value of $2.1 \times 10^{-14}$.

\subsection{Development of Assays for Chlorella Cell Wall Degrading Activity}

As described in the Materials and Methods section, two assays were developed for qualitative and quantitative assessment of chlorella cell wall degrading activity of A561L ${ }^{\mathrm{D}}$. The first is a quick and simple qualitative assay that relies on the natural resistance of the chlorella cells to nonionic and anionic detergents. To illustrate the assay, chlorovirus PBCV-1 particles were added to C. variabilis NC64A cells at a multiplicity of infection (MOI) of 5 and incubated for $15 \mathrm{~min}$; 1\% sodium dodecyl sulfate (SDS) was then added to the cells, the cells were centrifuged in a microcentrifuge and chlorophyll fluorescence was monitored in the supernatant fraction. Note that the virus infected cells led to the release of chlorophyll (red fluorescence color), whereas no chlorophyll was released from the control cells (Figure 2A). Similar results were obtained with C. heliozoae cells infected with virus ATCV-1 (Figure 2A) and M. conductrix cells infected with virus CVM-1 (results not shown). 
Addition of the viruses to non-host cells did not result in chlorophyll release because the viruses are specific for their hosts and do not attach to non-host cells [3].
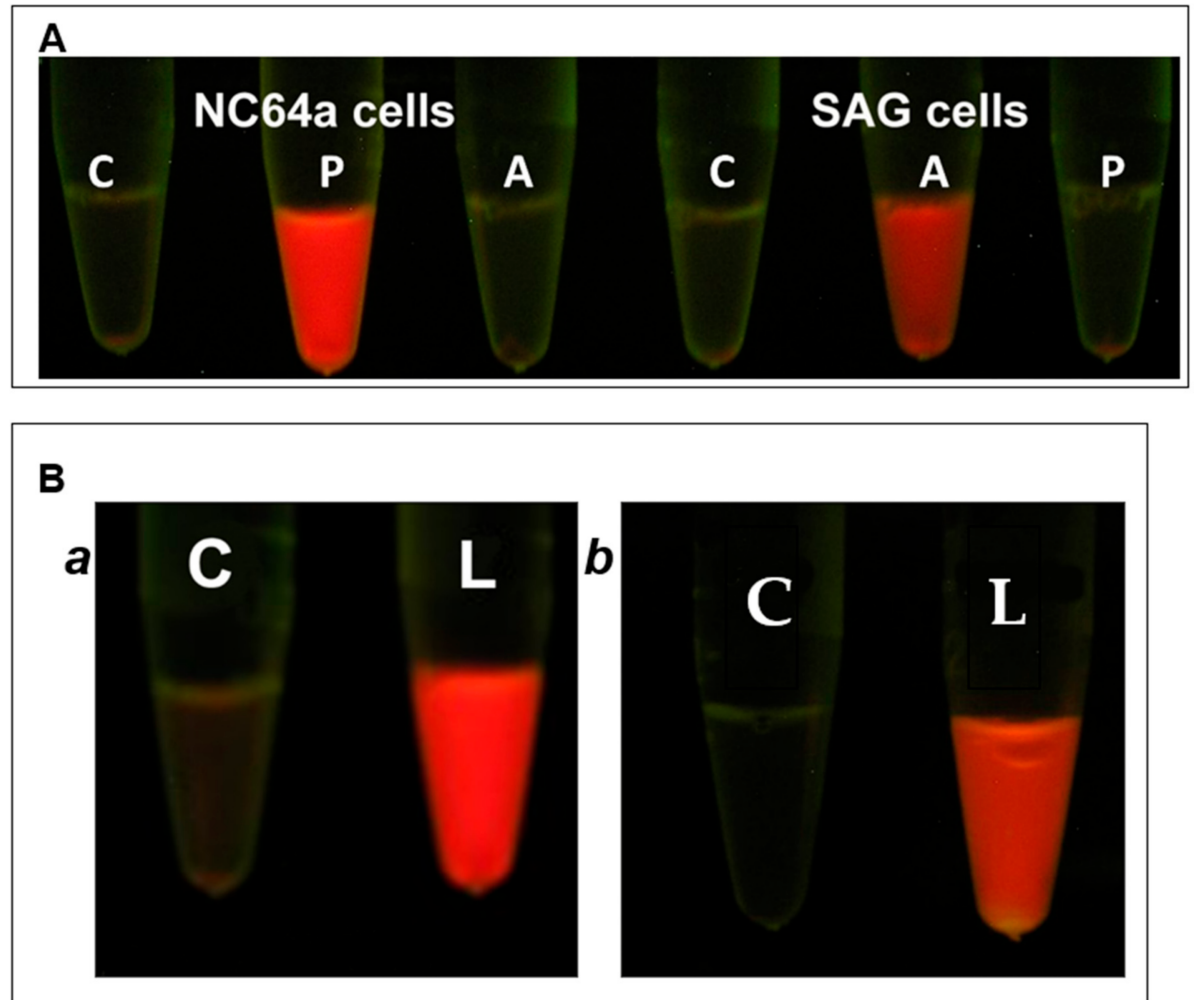

Figure 2. Specificity of the reaction of chlorella cells to virus infection and to virion associated cell wall degrading activity. (A). Exposure of chlorella host cells to chloroviruses PBCV-1 and ATCV-1. From left to right: $(\mathrm{C})$ control (intact $C$. variabilis NC64A cells treated with $1 \%$ SDS), $(\mathrm{P})$ C. variabilis NC64A cells plus intact PBCV-1, (A) C. variabilis NC64A cells plus intact ATCV-1 virus, (C) control (intact $C$. heliozoae SAG cells treated with $1 \%$ SDS), (A) C. heliozoae SAG cells plus intact ATCV-1 virus, (P) C. heliozoae SAG cells plus intact PBCV-1 virus. Cells (concentration $2 \times 10^{7}$ ) were infected with viruses at a MOI of 5 incubated for $15 \mathrm{~min}$ and SDS was added to $1 \%$. (Note: One obtains the same results if one uses Triton X-100 at the same concentration.) Note the specificity of chlorovirus infection. (B). Exposure of chlorella host cells to PBCV-1 vLysin: Panel $\boldsymbol{a}$ : C. variabilis NC64A cells, Panel $\boldsymbol{b}$ : $C$. heliozoae SAG cells. (C) Control (intact cells treated with 1\% SDS), (L) cells incubated with PBCV-1 vLysin. Cells (concentration $2 \times 10^{7}$ ) were treated with activity equivalent to $5 \times 10^{10} \mathrm{PFU} / \mathrm{mL}$ for 15 min followed by addition of SDS. Note that the PBCV-1 vLysin treatment resulted in the release of chlorophyll from both types of cells. Images were taken under UV light to evaluate the autofluorescence of chlorophyll (red).

Experiments to extract a cell wall degrading enzyme(s) from the three purified viruses led to the discovery that exposure of the viruses to $5 \mathrm{M} \mathrm{LiCl}$, followed by centrifugation, released a soluble fraction (termed vLysin) that made the three algal cells susceptible to $1 \%$ SDS. Furthermore, exposure of the three virus hosts to the vLysin from each of the viruses revealed that all the cells were susceptible to 1\% SDS. Therefore, the cell wall degrading activity packaged in the virions was not as specific as the viruses, i.e., the activity had a broader cell-type range than the viruses (Figure 2B).

The second assay employed chlorella ghost cells (algal cells extracted with methanol) dyed with calcofluor-white (CFW) [25]. Cell wall degrading activity was monitored by the amount of released dye. 


\subsection{Expression and Purification of $A 561 L^{D 4}$}

To explore A561L potential cell wall degrading activity two recombinant proteins were produced-intact A561L and a truncated portion of A561L that only contained the vAL-1 like domain, amino acids 413 to 649 (referred to as A561L ${ }^{\mathrm{D}}$ ). Despite trying many procedures, the intact recombinant A561L protein remained insoluble. However, most of the $\mathrm{A} 561 \mathrm{~L}^{\mathrm{D} 4}$ was in the soluble phase and the His-tag expressed protein was purified over a Ni-binding column. One liter of E. coli culture produced about $10 \mathrm{mg}$ of soluble recombinant $\mathrm{A} 561 \mathrm{~L}^{\mathrm{D}}$.

As reported in Figure 3, increasing concentrations of A561 $\mathrm{L}^{\mathrm{D} 4}$ resulted in the release of $\mathrm{CFW}$, demonstrating that the recombinant protein was active. Using the chlorophyll-release assay, $\mathrm{A} 561 \mathrm{~L}^{\mathrm{D} 4}$ was tested at different temperatures, $\mathrm{pHs}$, and cation requirements. The protein was active from $10^{\circ} \mathrm{C}$ to $60^{\circ} \mathrm{C}$, with an optimum near $37^{\circ} \mathrm{C}$, which is higher than the $25^{\circ} \mathrm{C}$ optimum temperature for growing the host and the virus. The protein was active in $\mathrm{pHs}$ from 5.5 to 10.0 with an optimum between $\mathrm{pH} 7.0$ and 8.0. The degradation activity was enhanced with $\mathrm{Ca}^{2+}$ and $\mathrm{Mg}^{2+}$ but it was also active without adding any

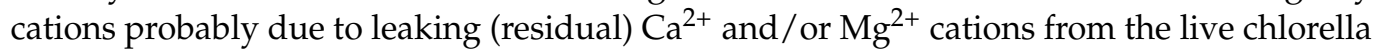
cells. Cell-wall degrading activity was inhibited by $\mathrm{Mn}^{2+}, \mathrm{Cu}^{2+}, \mathrm{Co}^{2+}, \mathrm{Fe}^{2+}, \mathrm{Zn}^{2+}, \mathrm{Ni}^{2+}$, EDTA and EGTA. The activity was destroyed by boiling or prior protease treatment.

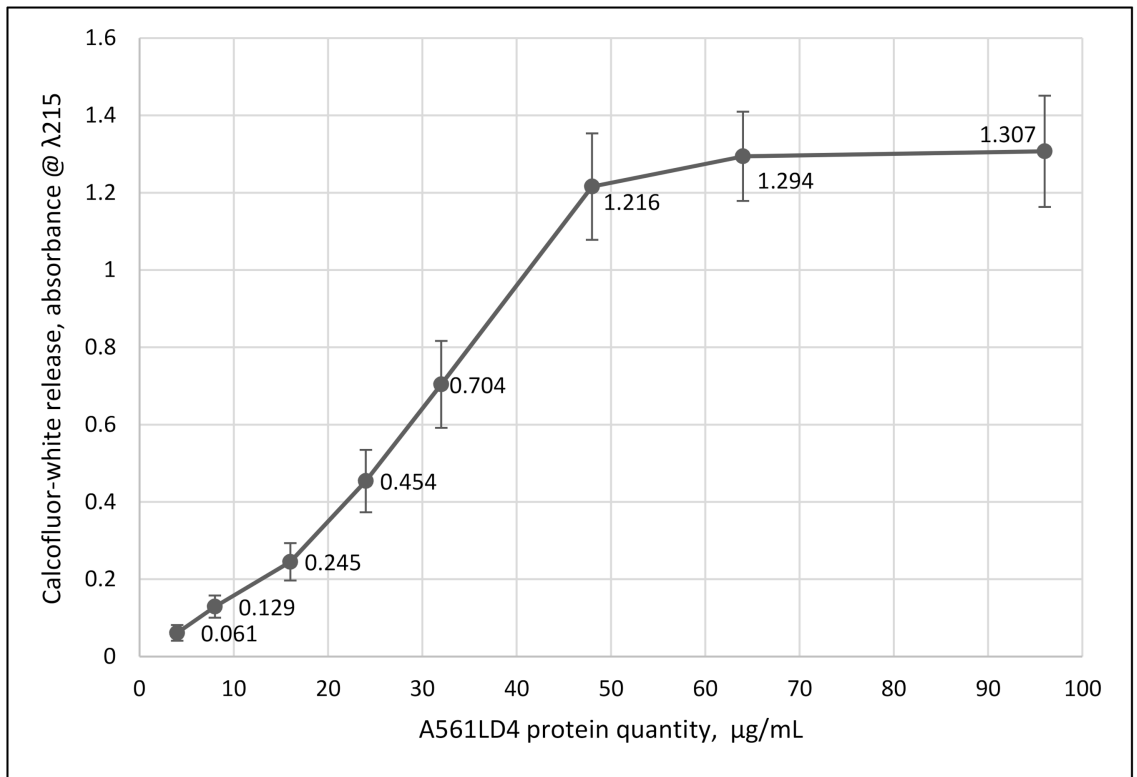

Figure 3. Specific activity of A561L $\mathrm{L}^{\mathrm{D} 4}$ assayed by CFW release. Ghost chlorella cells (at a concentration of $5 \times 10^{7} / \mathrm{mL}$ ) stained with CFW were treated with the specified amount of recombinant $\mathrm{A} 561 \mathrm{~L}^{\mathrm{D} 4}$ for $1 \mathrm{~h}$, then spun at $16,000 \times g$ for $15 \mathrm{~min}$. The supernatant fraction was removed and CFW release was measured at $\lambda=215 \mathrm{~nm}$. Results are plotted as mean \pm standard deviation $(n=10)$, $p$-value 0.0001 .

\subsection{Wall Degradation by $A 561 L^{D 4}$}

Exposure of live and ghost cells of $C$. variabilis NC64A to A561L ${ }^{\mathrm{D} 4}$ was examined by transmission electron microscopy (TEM). The walls were partially degraded by $10 \mathrm{~min}$ after addition of A561L $\mathrm{L}^{\mathrm{D}}$ (Figure 4). This was confirmed using the chlorophyll-release assay and CFW-release assay. 


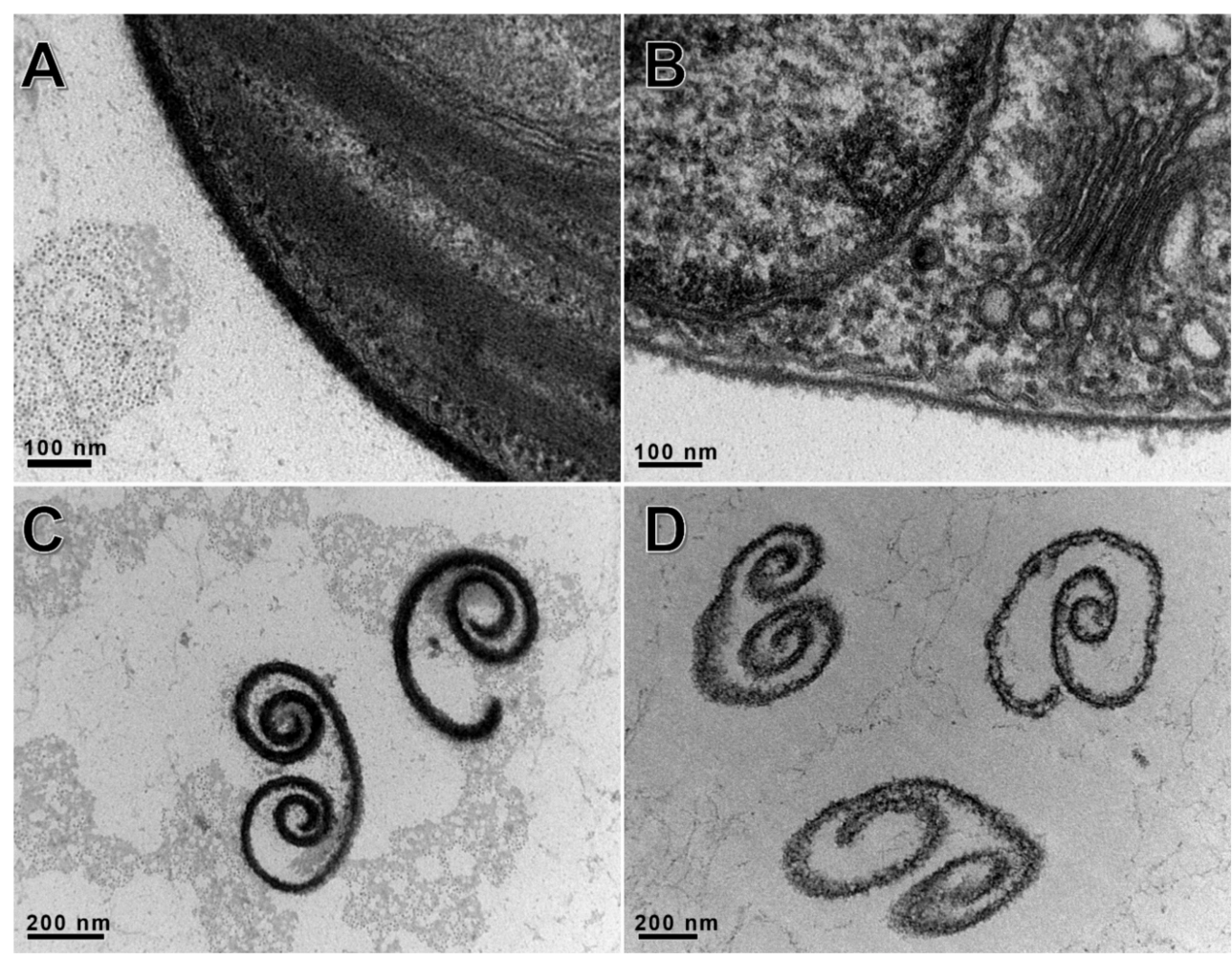

Figure 4. Degradation of $C$. variabilis NC64A cell walls after $10 \mathrm{~min}$ of digestion with $250 \mu \mathrm{g} / \mathrm{mL}$ of A561L ${ }^{\mathrm{D} 4}$ visualized by TEM. $(\mathbf{A}, \mathbf{C})$ were treated with the recombinant protein, $(\mathbf{B}, \mathbf{D})$ were controls. Top panels $(\mathbf{A}, \mathbf{B})$ represent live cells and bottom panels $(\mathbf{C}, \mathbf{D})$ cell wall fragments.

We hypothesized that $\mathrm{A} 561 \mathrm{~L}^{\mathrm{D} 4}$ treatment of isolated cell walls resulted in (i) the inactivation of the PBCV-1 receptor, and/or (ii) blocking the ability of the virus to adsorb to the cell. To test these two hypotheses, we isolated C. variabilis NC64A ghost cells $\left(5-6 \times 10^{7}\right.$ cells $\left./ \mathrm{mL}\right)$, incubated them with different concentrations of $\mathrm{A} 561 \mathrm{~L}^{\mathrm{D} 4}$ for various times, and collected the resulting residual cell wall material by centrifugation. The pellet fraction was re-suspended in TB and tested for its ability to interfere with PBCV-1 infectivity by incubating the fraction with virus, then evaluating by the plaque assay. As reported in Figure 5, increasing protein concentration and incubation time led to a decrease in the ability of the A561L $\mathrm{L}^{\mathrm{D} 4}$-treated ghost cells to bind PBCV-1. The first conclusion from this experiment is that the host cell wall receptor for the virus was inactivated by exposure to $\mathrm{A} 561 \mathrm{~L}^{\mathrm{D} 4}$; however, it is also possible that $\mathrm{A} 561 \mathrm{~L}^{\mathrm{D} 4}$ was blocking the virus receptor such that the virus was unable to bind to the ghost cell.

The supernatant fraction was collected in the above experiment and used to determine if A561 $\mathrm{L}^{\mathrm{D} 4}$-treated ghost cells resulted in the release of a soluble factor that prevented PBCV-1 adsorbing to the live cells. If this occurred, the soluble factor could be the intact viral binding receptor, which would prevent the virus from binding to the algal cell to initiate infection in the plaque assay. However, as reported in Figure 6, exposure of PBCV-1 to the supernatant fraction prior to the plaque assay did not result in a decrease in PBCV-1 titers. Therefore, the A561 $\mathrm{L}^{\mathrm{D} 4}$-treated ghost cell wall did not release a soluble factor capable of blocking virus adsorption, thereby excluding the presence of an intact cell-wall receptor in the soluble fraction. Currently, the nature of the chlorovirus receptor is unknown, but treating ghost cell walls with standard proteases does not interfere with virus binding; however, certain alginate lyase preparations reduce virus binding, suggesting that the receptor is composed of a type of carbohydrate [24]. 


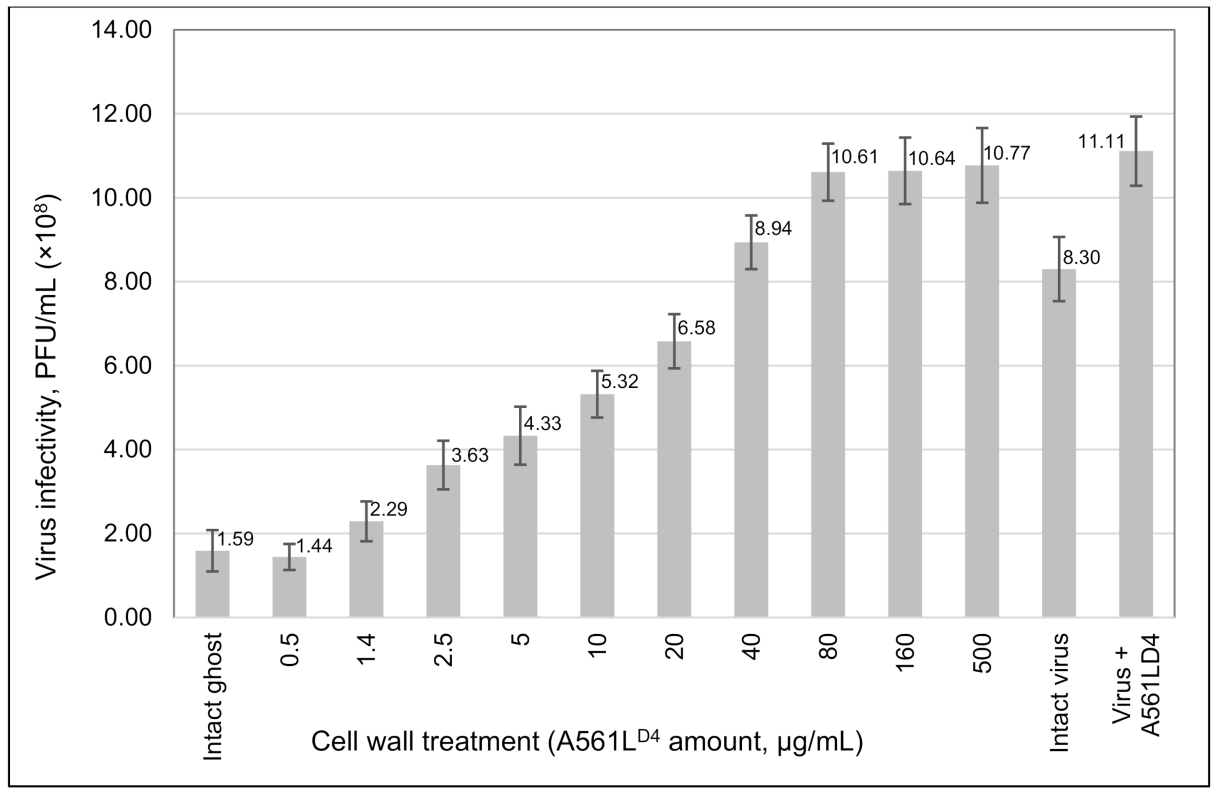

Figure 5. Effect of $A 561 \mathrm{~L}^{\mathrm{D} 4}$ treatment of $C$. variabilis ghost cells on $\mathrm{PBCV}-1$ virus receptors. Ghost cells $\left(10^{8}\right.$ cells $\left./ \mathrm{mL}\right)$ in TB with $10 \mathrm{mM} \mathrm{CaCl}_{2}$ were treated with various amounts of $\mathrm{A} 561 \mathrm{~L}^{\mathrm{D} 4}$ for $24 \mathrm{~h}$. After incubating the ghost cells, the reactions were centrifuged for $15 \mathrm{~min}$ at $16,000 \times g$, (the supernatant fractions were collected for the experiments in Figure 6), and the pelleted cells were washed with TB one time and then re-suspended in $200 \mu \mathrm{L}$ of TB with $10 \mathrm{mM} \mathrm{CaCl}_{2}$. PBCV-1 virus was added to the treated ghost cells at a MOI of 10 and incubated for $1 \mathrm{~h}$ at room temperature. Serial dilutions of the reaction were made and virus infectivity was plaque assayed. Results are plotted as mean \pm standard deviation $(n=10), p$-value 0.0001 .

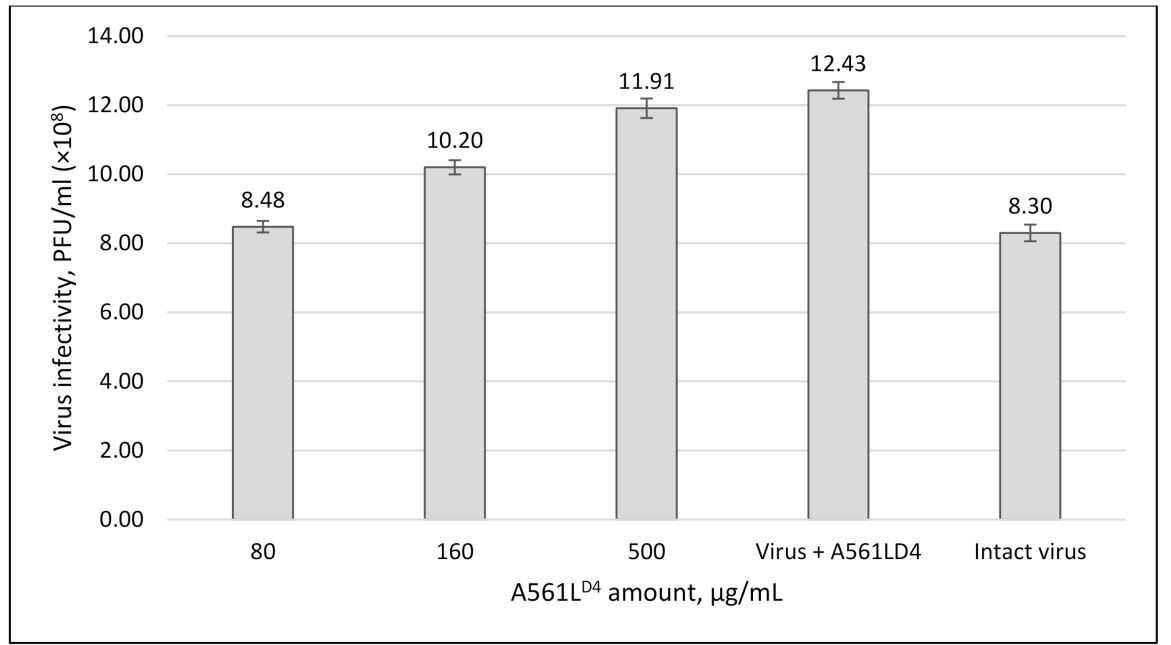

Figure 6. Effect of the soluble product resulting from A561L ${ }^{\mathrm{D} 4}$ treatment of $C$. variabilis NC64A ghost cells on PBCV-1 virus infectivity to determine if $A 561 \mathrm{~L}^{\mathrm{D} 4}$ treatment resulted in the release of intact host receptor. Supernatant fractions collected from the experiment in Figure 5 were collected and PBCV-1 virus was added to the collected supernatant fraction at a concentration of $10^{9} \mathrm{PFU} / \mathrm{mL}$ and incubated for $\sim 1 \mathrm{~h}$ at room temperature. Serial dilutions of the supernatant fractions were made and virus infectivity was plaque assayed. Clearly, the host receptor was not released intact by A561LD4. Note, however, that exposure of purified PBCV-1 to A561L ${ }^{\mathrm{D} 4}$ resulted in an $~ 50 \%$ increase in the specific infectivity of PBCV-1. Results are plotted as mean \pm standard deviation $(n=10), p$-value 0.0001 . 


\subsection{A561L $L^{D 4}$ Treatment Increased PBCV-1 Infectivity}

As a control in the previous experiment, highly purified PBCV-1 was incubated with A561 $\mathrm{L}^{\mathrm{D} 4}$ and we were surprised to discover that exposure of PBCV-1 to A561L ${ }^{\mathrm{D} 4}$ resulted in an almost $50 \%$ increase in the specific infectivity of PBCV-1 compared to untreated, purified PBCV-1 (Figure 6). It is worth noting that we repeatedly observed similar increases in virus specific infectivity after treatment with vLysin [25].

We have previously reported that about 25 to $30 \%$ of highly purified PBCV- 1 virions form plaques [29]. We suspect that this unexpected finding occurred because the purified viruses contained residual host receptor material attached to their spike structures. This putative residual receptor material was then digested by $\mathrm{A} 561 \mathrm{~L}^{\mathrm{D} 4}$, leading to an increase in infectious viruses.

\subsection{Immunological Detection of the A561L Protein in the Virion}

We examined the possibility that A561L might be post-translationally cleaved into two or more peptides, including one peptide consisting solely of $\mathrm{A} 561 \mathrm{~L}^{\mathrm{D} 4}$ in the virus particle. However, two experiments ruled out this possibility. First, the mass spectrometry proteomic data suggested that the entire protein was present in the virion [16].

Second, a mouse polyclonal antibody to $\mathrm{A} 561 \mathrm{~L}^{\mathrm{D} 4}$ was produced and used in a western blot analysis of total PBCV-1 protein. The blot indicated that the antibody reacted with a protein of about $72 \mathrm{kD}$, the expected size of A561L (Figure 7, band a). However, unexpectedly $\mathrm{LiCl}$ extracted vLysin led to the formation of a $42 \mathrm{kDa}$ protein (Figure 7, band $\mathbf{b}$ ). This unexpected finding suggests that the A561L protein might have a protease sensitive region that leads to the release of a C-terminal end peptide approximately encompassing both domain three (A561 $\left.{ }^{\mathrm{D} 3}\right)$ and domain four $\left(\mathrm{A} 561 \mathrm{~L}^{\mathrm{D} 4}\right)$. At this point we do not know if this cleavage actually occurs during virus infection. However, it is worth noting that domain two $\left(\mathrm{A} 561^{\mathrm{D} 2}\right)$ resembles a peptidase $\mathrm{S} 8$ domain-containing protein from Tetradesmus obliquus with an E-value of $9.3 \times 10^{-8}$. This putative peptidase domain might serve as a cis-acting protease and cleave itself under appropriate conditions.

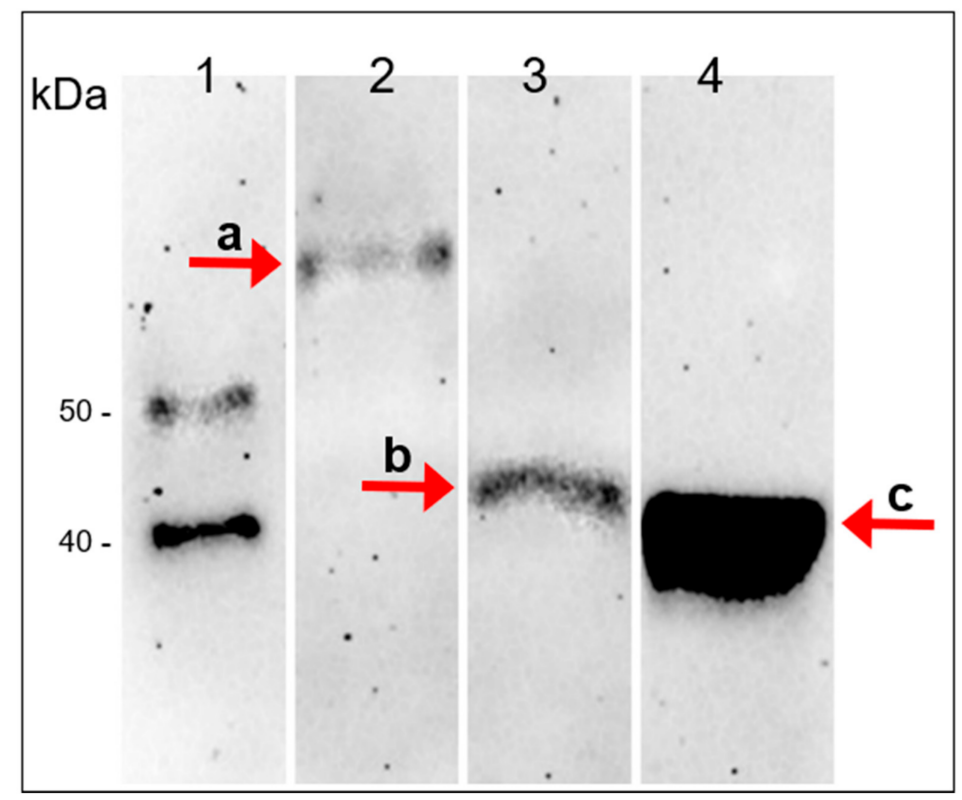

Figure 7. Presence of A561L protein in the PBCV-1 virion. Western blot of PBCV-1 proteins against anti $\mathrm{A} 561 \mathrm{~L}^{\mathrm{D} 4}$ antibody $(\mathrm{AB})$ produced in mice. (1). protein ladder; (2). untreated virus; (3). virus treated with $5 \mathrm{M} \mathrm{LiCl}$ (vLysin); (4). recombinant A561L ${ }^{\mathrm{D}}$. Band a full length A561L protein $72 \mathrm{kDa}$; band $\mathbf{b}$ processed fragment of A561L $\sim 44 \mathrm{kDa}$ (vLysin activity); band c recombinant A561L ${ }^{\mathrm{D} 4}$ protein $\sim 42 \mathrm{kDa}$ (the A561LD 4 domain is $\sim 27 \mathrm{kDa}$ plus His-Patch thioredoxin, V5 epitope tag and 6xHis tags). 


\subsection{A561L Is Located Inside the PBCV-1 Virion}

Two experiments indicate that A561L is probably located inside the PBCV-1 particle rather than on the surface. First, treatment of purified viruses with proteinase K had no effect on virus infectivity as judged by the plaque assay [16]. Second, addition of antiA561L $\mathrm{L}^{\mathrm{D}}$ polyclonal antibody to PBCV-1 significantly decreased the virus's ability to digest the host's cell wall (down to $22 \%$ compare to control) but did not terminate it completely as judged by the chlorophyll release assay (data not shown). Therefore, we suspect that the protein is located either inside the PBCV-1 spike structure or in the cavity that is located between the virus internal membrane and the base of the spike (see Figure 3a in Zhang et al. [9]).

The anti-A561 $\mathrm{L}^{\mathrm{D} 4}$ antiserum was also used to determine if vLysin wall-degrading activity was the only cell wall degrading activity packaged in the virion. As reported in Figure 8 , addition of the anti-A561 $\mathrm{L}^{\mathrm{D} 4}$ antiserum at 800 -fold dilutions to vLysin blocked chlorophyll release from $C$. variabilis NC64A. This complete inhibition of activity indicates that $\mathrm{A} 561 \mathrm{~L}^{\mathrm{D} 4}$ is probably the only cell wall degrading activity in the virion.

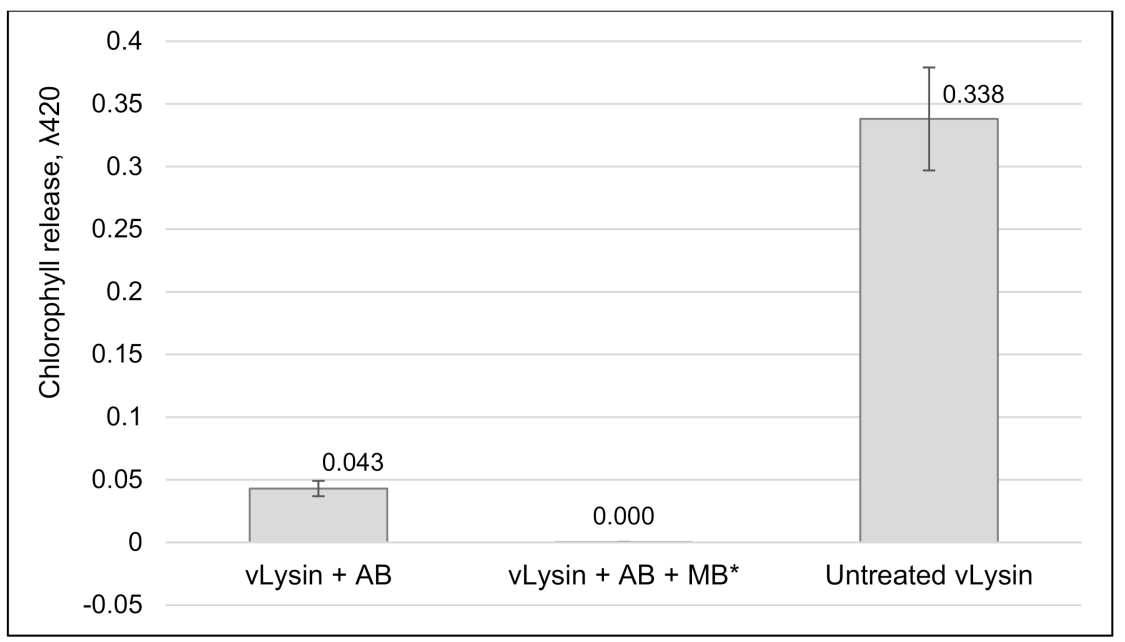

Figure 8. Effect of anti A561L ${ }^{\mathrm{D} 4} \mathrm{AB}$ on vLysin activity. PBCV-1 isolated vLysin was treated with anti A561L $\mathrm{L}^{\mathrm{D} 4}$ antibody (AB) produced in mice (800-fold dilution) for $1 \mathrm{~h}$. After the incubation, anti-mouse $\mathrm{Ig} \mathrm{MB}$ were added to the reaction and the supernatant fraction was separated from the magnetic beads following the manufacturer's instructions. Antibody treated vLysin was mixed with NC64A cells and incubated for $1 \mathrm{~h}$. The treated cells were subject to 1\% SDS, spun down, the supernatant fraction was removed and chlorophyll release was measured at $\lambda=420$. Untreated PBCV-1 vLysin was used as a positive control. NC64A cells treated with pre-bleed serum served as a negative control. Results are plotted as mean \pm standard deviation $(n=4), p$-value 0.0001 . $\left.{ }^{*}\right)$ A mean of standard deviation for vLysin $+\mathrm{AB}+\mathrm{MB}$ was 0.0002 .

\subsection{A561L $L^{D 4}$ Homologs Are Common among the Chloroviruses}

If A561L is important for virus genome entry into its host, it would be expected to be present in all of the chloroviruses. Therefore, annotated genomes of 52 chloroviruses were searched for homologs to the $a 561 l$ gene. The investigation revealed that all 52 sequenced viruses encoded an A561L-like protein with a lyase domain (i.e., D4 like) located in the C-terminus of the protein. A clustalW alignment of A561L homologs from eight chloroviruses plus PBCV-1, consisting of two representatives from each of the four subtypes of chloroviruses is reported in Figure 9. Overall, there was $\sim 32 \%$ amino acid identity and $48 \%$ amino acid similarity in the A561L homologs among the 52 viruses. Therefore, A561L was considered a core chlorovirus protein. 


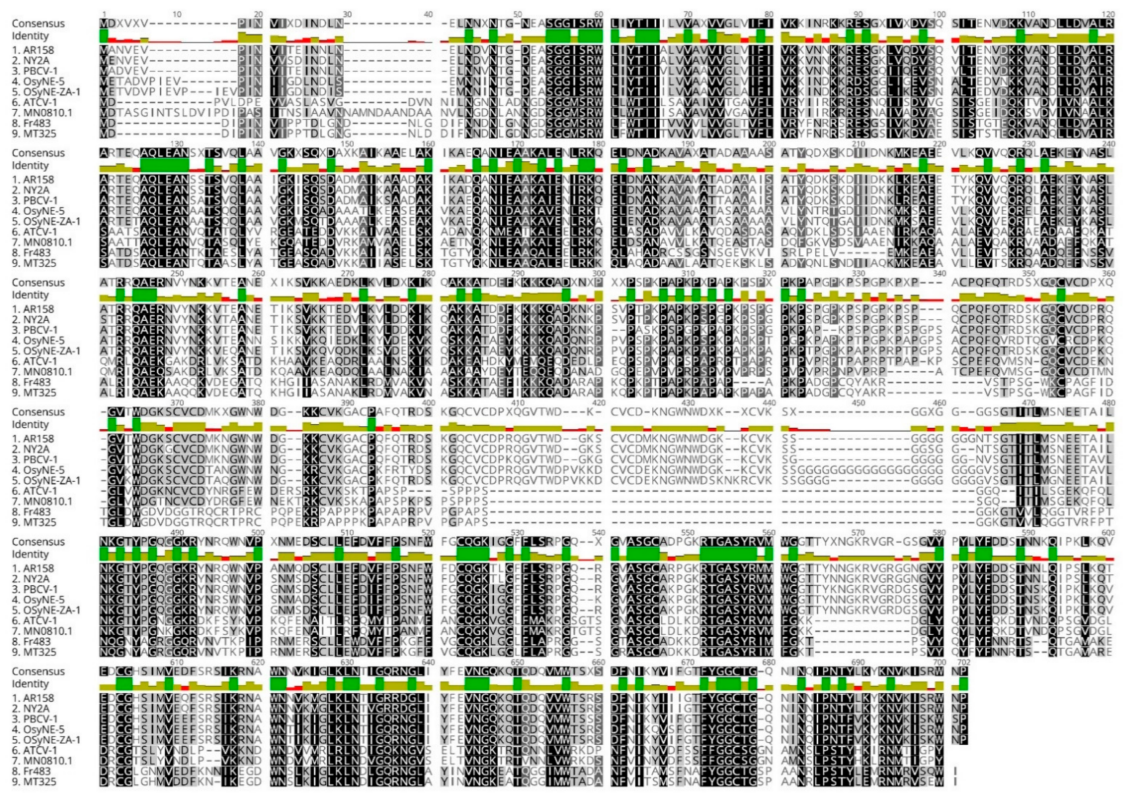

Figure 9. ClustalW alignment of A561L homologs among representatives of four clades of chloroviruses. The similarity of amino acids in the sequence alignment is shown as follows: black being identical, different shades of gray (different levels of conservation) and white not conserved. On the top ribbon: green color denotes identical amino acids. Other shades of amino acids indicate a level of conservation from olive color as being the most conserved to red color not conserved. AR-158, NY-2A along with PBCV-1 are NC64A viruses; OsyNE-5 and OsyNE-ZA-1 infect Syngen strain; ATCV-1 and MN0810.1 are SAG viruses; Fr-483 and MT325 are Pbi viruses. A561L ${ }^{D 1}$ domain ends at aa 93, domain A561L ${ }^{\mathrm{D} 2}$ stretches from aa 94 to aa 338 , domain $\mathrm{A} 561 \mathrm{~L}^{\mathrm{D} 3}$ runs from aa 339 to aa 456 and domain $\mathrm{A} 561 \mathrm{~L}^{\mathrm{D} 4}$ starts at 457 aa.

\subsection{Phylogenetic Analysis of A561L}

Homologs of A561L protein coded by the 52 chloroviruses were aligned and a phylogenetic tree was constructed using PhyML, a maximum likelihood method (Figure 10). Alignment results showed that the most conserved A561L domains are domain $2\left(\mathrm{~A}_{561 \mathrm{~L}^{\mathrm{D}}}\right)$ and domain $4\left(\mathrm{~A}_{561 \mathrm{~L}^{\mathrm{D}}}\right)$. The A561L proteins clustered into the four clades of chloroviruses that are based on their algal hosts.

The percent amino acid identity between the clades representing the different host/virus groups was: $27.9-36.0 \%$ identity between NC64A-SAG clusters, $32.2-38.4 \%$ identity between NC64A-Pbi clusters and 36.9-41.7\% identity between Pbi-SAG clusters. The range of protein sequence identity within-clades was $65.0-100 \%, 73.4-100 \%$ and $71.1-100 \%$ identity for NC64A, SAG and Pbi viruses, respectively. 


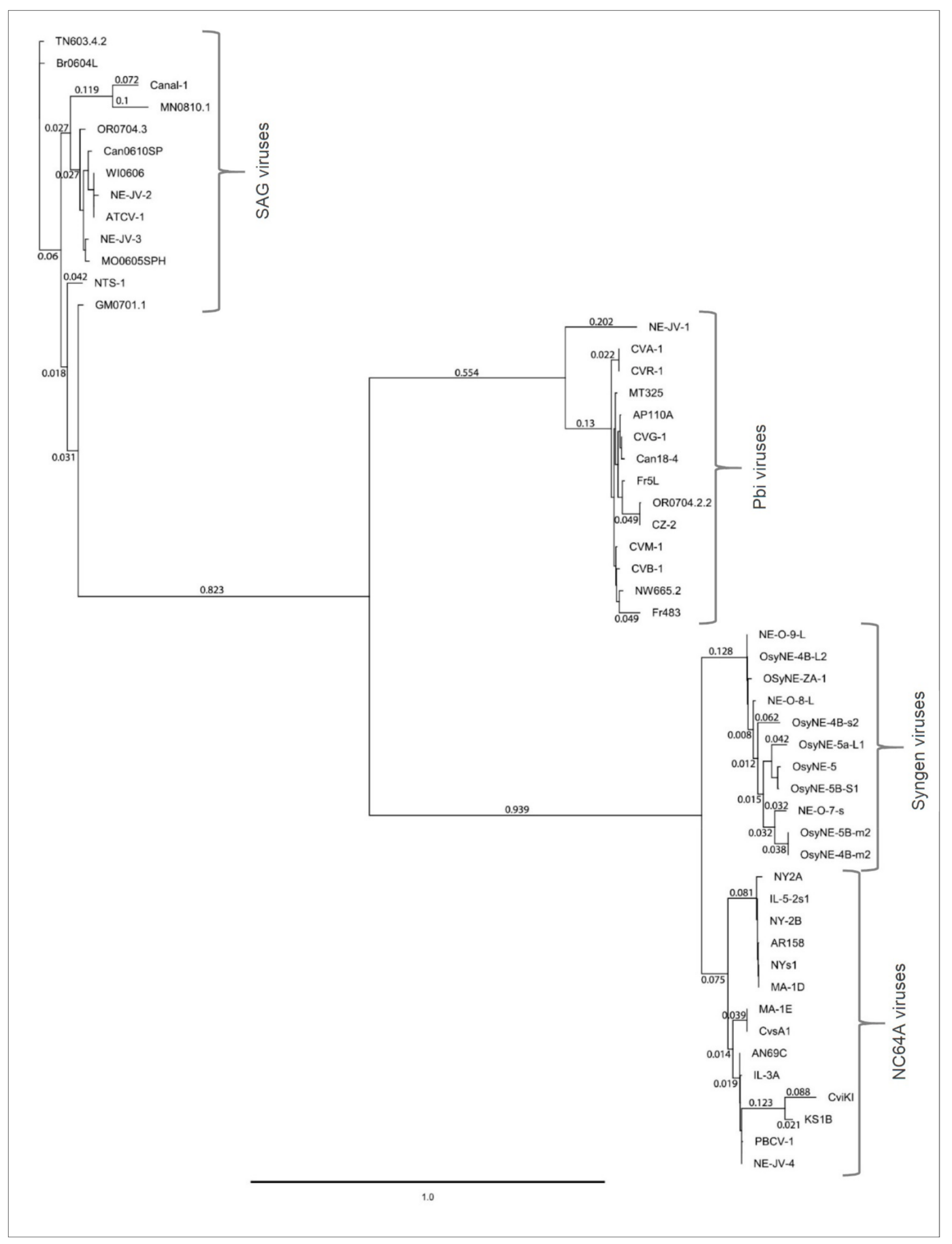

Figure 10. Phylogeny of A561L protein from 52 chloroviruses. Phylogenetic tree was constructed with Geneious plugin program PhyML 3.3.20180621 (Maximum likelihood) [33] using the default settings. The bar indicates the number of substitutions per site and branch length shows dissimilarity between strains.

\subsection{A561L D4 Degrades the Cell Wall of Several Chlorella Species}

To determine the specificity of $\mathrm{A} 561 \mathrm{~L}^{\mathrm{D} 4}$ activity, the protein was tested on 27 green algal isolates (Table 1). However, it was first necessary to establish that the algal isolates were resistant to $1 \%$ SDS as judged by the chlorophyll-release assay (Figure 2A). The results (not shown) demonstrated that all algal isolates were resistant to $1 \%$ SDS. Therefore, each of the 27 algal isolates (at a concentration of $2 \times 10^{7}$ cells $/ \mathrm{mL}$ ) were exposed to $100 \mu \mathrm{g} / \mathrm{mL}$ of $\mathrm{A} 561 \mathrm{~L}^{\mathrm{D} 4}$ for $1 \mathrm{~h}$ and examined for chlorophyll release. The range of the released chlorophyll cannot be directly compared between algal isolates due to the innate 
differences in the strain physiology and cell chlorophyll content. The experiment showed that $\mathrm{A} 561 \mathrm{~L}^{\mathrm{D} 4}$ was active on the other three chlorovirus hosts, C. variabilis Syngen 2-3, C. heliozoae and M. conductrix, as well as eight other green algal isolates (Table 1).

Table 1. Sensitivity of different green algae to recombinant $A 561 \mathrm{~L}^{\mathrm{D} 4}$ overexpressed protein.

\begin{tabular}{|c|c|c|}
\hline Species & Strain Designation & Chlorophyll Release, $\lambda=420^{\#}$ \\
\hline Auxenochlorella protothecoides & stock 29 & 0.840 \\
\hline Chlorella heliozoae & SAG 3.83 & 0.570 \\
\hline Chlorella miniata & UTEX 490 & 0.198 \\
\hline Chlorella sorokiniana & UTEX 246 & 0.335 \\
\hline Chlorella sorokiniana & UTEX 1810 & 0.294 \\
\hline Chlorella sorokiniana & UTEX 1230 & 0 \\
\hline Chlorella sorokiniana & CS01 China & 0 \\
\hline Chlorella variabilis & NC64A & 0.267 \\
\hline Chlorella variabilis & NIES 2540 & 0.236 \\
\hline Chlorella variabilis & NIES 2541 & 0.368 \\
\hline Chlorella variabilis & Syngen 2-3 & 0.229 \\
\hline Chlorella vulgaris & UTEX 395 & 0.687 \\
\hline Chlorella sp. & UTEX BSN 069 & 0.681 \\
\hline Chlorella sp. & UTEX BSN069 & 0.507 \\
\hline Chloroidium saccharophilum & UTEX 247 & 0 \\
\hline Coccomyxa subellipsoidea & C169 & 0 \\
\hline Micractinium conductrix & $\mathrm{Pbi}$ & 0.376 \\
\hline Parachlorella kessleri & UTEX 2228 & 0 \\
\hline Scenedesmus dimorphus & UTEX 417 & 0.392 \\
\hline Scenedesmus dimorphus & UTEX 1237 & 0 \\
\hline Scenedesmus obliquus & UTEX B2630 & 0 \\
\hline Scenedesmus obliquus & UTEX 393 & 0 \\
\hline Scenedesmus obliquus & UTEX 1450 & 0 \\
\hline Scenedesmus parisiensis & UTEX 1585 & 0 \\
\hline Scenedesmus sp & UTEX 1590 & 0 \\
\hline Scenedesmus sp & UTEX 1589 & 0 \\
\hline Scenedesmus sp & UTEX 2193 & 0 \\
\hline Scenedesmus sp & UTEX 1591 & 0 \\
\hline
\end{tabular}

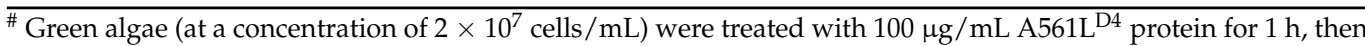
treated with $1 \%$ SDS, incubated for $1 \mathrm{~min}$; cells were spun down for $15 \mathrm{~min}$ at $16,000 \times \mathrm{g}$; the supernatant fraction was removed and chlorophyll release was measured at $\lambda=420$. Control cells were treated with TB.

The green alga, Chlamydomonas reinhardtii, which has a very different cell wall composition [40] than Chlorella (e.g., [41]), was sensitive to all the detergents that we tested and so it could not be assayed for sensitivity to $\mathrm{A} 561 \mathrm{~L}^{\mathrm{D} 4}$ using the chlorophyll release assay.

\section{Conclusions}

Unexpectedly, none of the five previously characterized virus-encoded polysaccharide degrading enzymes are packaged in the PBCV-1 virion; consequently, they were eliminated as candidates for cell wall penetration during the entry phase of PBCV-1 infection of its host, C. variabilis NC64A. However, A561L is a virus-encoded protein that is found in the virion, 
and we provide evidence that it is involved in degrading the host cell wall during viral entry. The A561L protein has four putative domains; the C-terminal domain consisting of 237 amino acids has the cell wall degrading activity, which we referred to as $\mathrm{A} 561 \mathrm{~L}^{\mathrm{D} 4}$. A561L ${ }^{D 4}$ was expressed as a recombinant soluble protein and shown to partially degrade C. variabilis NC64A cell walls. All 52 chloroviruses that have been sequenced, infecting four different hosts, had an $a 5611$ homolog and the cell wall of all four chlorovirus hosts, as well as several non-host Chlorella spp., were partially degraded by A561L ${ }^{\mathrm{D}}$. Thus, A561L ${ }^{\mathrm{D} 4}$ was not cell-type-specific. Finally, we discovered that exposure of highly purified PBCV-1 virions to $\mathrm{A} 561 \mathrm{~L}^{\mathrm{D} 4}$ increased the specific infectivity of PBCV-1 from about $25-30 \%$ of the virus particles forming plaques to about $50 \%$ of the particles forming plaques. We attribute this increase to removal of residual putative host receptor material that was attached to newly replicated viruses in the cell lysates.

Supplementary Materials: The following are available online at https:/ / www.mdpi.com/article/10.339 0/v13050782/s1, Table S1: Attributes and sequences of chlorovirus encoded homologs of A561L gene.

Author Contributions: Conceptualization, J.L.V.E.; methodology, I.V.A., L.C.L. and A.M.; software, I.V.A., J.S.G. and G.A.D.; validation, I.V.A., J.L.V.E., L.C.L., J.S.G. and A.M.; formal analysis, I.V.A., J.L.V.E. and D.D.D.; investigation, I.V.A., L.C.L., C.F.Q., E.M., A.E. and J.S.G.; resources, J.L.V.E., A.M.; data curation, I.V.A. and J.S.G.; writing—original draft preparation, J.L.V.E. and I.V.A.; writingreview and editing, J.L.V.E., I.V.A., D.D.D.; visualization, I.V.A. and L.C.L.; supervision, J.L.V.E. and I.V.A.; project administration, J.L.V.E.; funding acquisition, J.L.V.E. and D.D.D. All authors have read and agreed to the published version of the manuscript.

Funding: This research was partially supported by the Stanley Medical Research Institute Grant 11R-0001 (J.L.V.E. and D.D.D.), NSF-EPSCoR grant EPS-1004094 (J.L.V.E.), NSF-EPSCoR grant 1736030 (J.L.V.E.), University of Nebraska Agricultural Research Division, University of Nebraska-Lincoln Office of Research \& Economic Development grant 2112206001 (D.D.D.) and the COBRE program of the National Center for Research Resources Grant P20-RR15535 (J.L.V.E.).

Institutional Review Board Statement: Not applicable.

Informed Consent Statement: Not applicable.

Acknowledgments: We thank summer students Swetha Tatineni and Fatima Al-Sammak for their help with the lysing assays and Joshua Maynor for helping to purify the recombinant A561L ${ }^{\mathrm{D} 4}$ protein.

Conflicts of Interest: The funders had no role in the design of the study; in the collection, analyses, or interpretation of data; in the writing of the manuscript, or in the decision to publish the results.

\section{Appendix A}

Table A1. Summary of Phyre2 top four templates for protein structure prediction.

\begin{tabular}{ccccc}
\hline Template, PDB & Template Information & Confidence, \% & \% i.d. & \% of Coverage \\
\hline c5gmtB & $\begin{array}{c}\text { crystal structure of the marine pl-14 } \\
\text { alginate lyase from Aplysia kurodai }\end{array}$ & 100 & 23 & 85 \\
\hline c6kcvB & $\begin{array}{c}\text { structure of alginate lyase from } \\
\text { Chitinophaga sp. MD30 aly36b mutant } \\
\text { k143a/y185a in complex with alginate } \\
\text { tetrasaccharide }\end{array}$ & 100 & 23 & 30 \\
\hline c3im0A & crystal structure of chlorella virus Val-1 & 100 & 16 \\
c2zzjA & $\begin{array}{c}\text { crystal structure of } \\
\text { endo-beta-1,4-glucuronan lyase from } \\
\text { fungus Trichoderma reesei }\end{array}$ & 99.7 & 79 \\
\hline
\end{tabular}



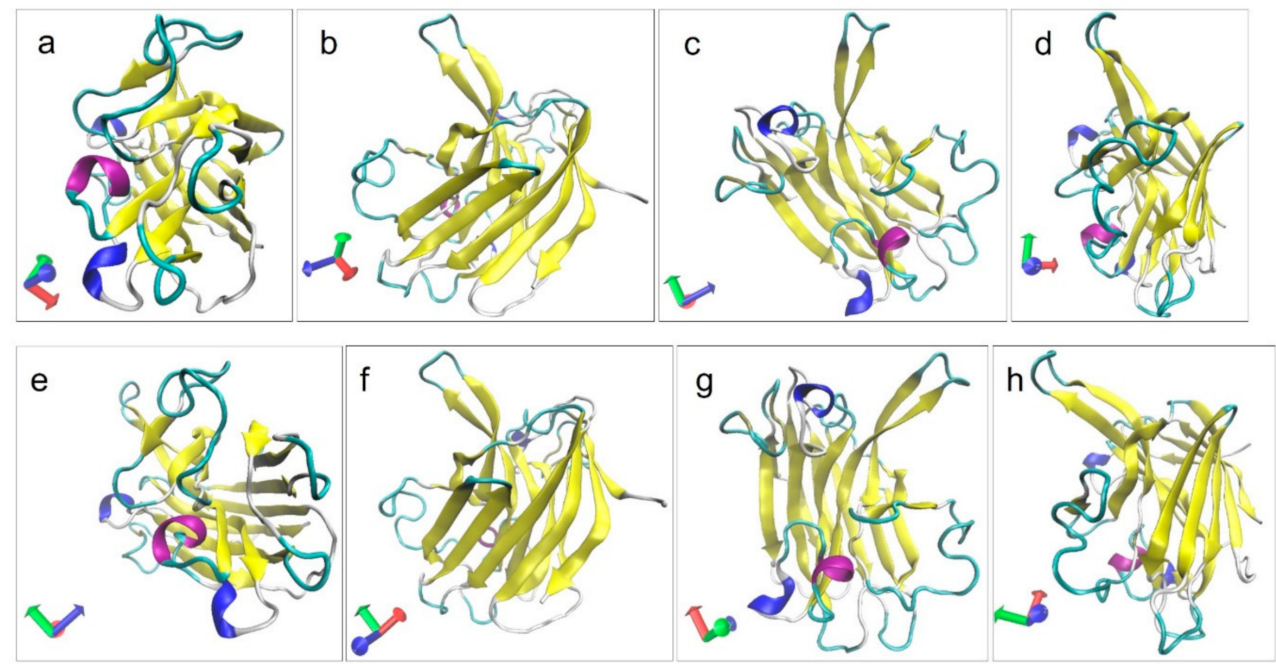

Figure A1. Predicted alginate lyase structure of A561L $\mathrm{L}^{\mathrm{D}}$ protein based on remote homology. Protein ribbon model colors are based on a secondary structure. Top row (a-d): views of A561LD4 3D protein model from different dimensions; bottom row (e-h): view of 3D crystal structure of the marine pl-14 alginate lyase from Aplysia kurodai from different dimensions.

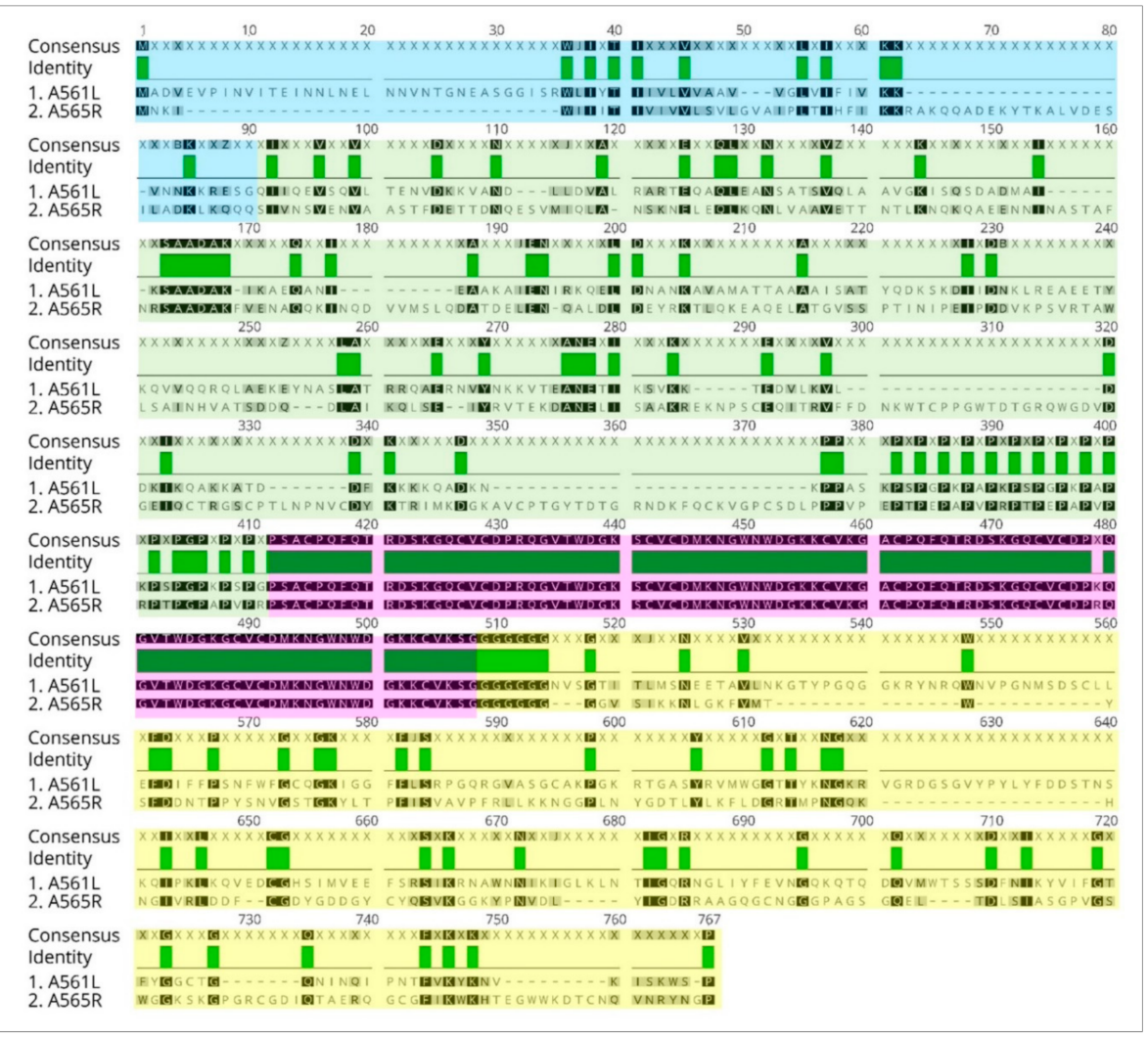

Figure A2. Pairwise amino acid alignment of A561L and A565R PBCV-1 proteins using Geneious 11.0.5 software. Green color denotes identical amino acids. Predicted domains in A561L: Domain 1 is highlighted in blue (69 aa); Domain 2 is highlighted in green (241 aa); Domain 3 is highlighted in pink (96 aa); and Domain 4 highlighted in yellow is an alginate lyase domain (242 aa).

\section{References}

1. Nelson, D.C.; Schmelcher, M.; Rodriguez-Rubio, L.; Klumpp, J.; Pritchard, D.G.; Dong, S.; Donovan, D.M. Endolysins as antimicrobials. Adv. Virus Res. 2012, 83, 299-365.

2. Carter, J.B.; Saunders, V.A. Virology: Principles and Applications, 2nd ed.; John Wiley \& Sons: Hoboken, NJ, USA, $2014 ;$ p. 400. 
3. Van Etten, J.L.; Agarkova, I.V.; Dunigan, D.D. Chloroviruses. Viruses 2020, 12, 20. [CrossRef]

4. Proschold, T.; Darienko, T.; Silva, P.C.; Reisser, W.; Krienitz, L. The systematics of zoochlorella revisited employing an integrative approach. Environ. Microbiol. 2011, 13, 350-364. [CrossRef]

5. Hoshina, R.; Iwataki, M.; Imamura, N. Chlorella variabilis and Micractinium reisseri sp. nov. (Chlorellaceae, Trebouxiophyceae): Redescription of the endosymbiotic green algae of Paramecium bursaria (Peniculia, Oligohymenophorea) in the 120th year. Psychol. Res. 2010, 58, 188-201.

6. Quispe, C.F.; Esmael, A.; Sonderman, O.; McQuinn, M.; Agarkova, I.; Battah, M.; Duncan, G.A.; Dunigan, D.D.; Smith, T.P.L.; De Castro, C.; et al. Characterization of a new chlorovirus type with permissive and non-permissive features on phylogenetically related algal strains. Virology 2017, 500, 103-113. [CrossRef]

7. Arriola, M.B.; Velmurugan, N.; Zhang, Y.; Plunkett, M.H.; Hondzo, H.; Barney, B.M. Genome sequences of Chlorella sorokiniana UTEX 1602 and Micractinium conductrix SAG 241.80: Implications to maltose excretion by a green alga. Plant J. 2018, 93, 566-586. [CrossRef]

8. Cherrier, M.V.; Kostyuchenko, V.A.; Xiao, C.; Bowman, V.D.; Battisti, A.J.; Yan, X.; Chipman, P.R.; Baker, T.S.; Van Etten, J.L.; Rossmann, M.G. An icosahedral algal virus has a complex unique vertex decorated by a spike. Proc. Natl. Acad. Sci. USA 2009, 106, 11085-11089. [CrossRef]

9. Zhang, X.; Xiang, Y.; Dunigan, D.D.; Klose, T.; Chipman, P.R.; Van Etten, J.L.; Rossmann, M.G. Three-dimensional structure and function of the Paramecium bursaria chlorella virus capsid. Proc. Natl. Acad. Sci. USA 2011, 108, 14837-14842. [CrossRef]

10. Meints, R.H.; Lee, K.; Burbank, D.E.; Van Etten, J.L. Infection of a chlorella-like alga with the virus, PBCV-1: Ultrastructural studies. Virology 1984, 138, 341-346. [CrossRef]

11. Milrot, E.; Shimoni, E.; Dadosh, T.; Rechav, K.; Unger, T.; Van Etten, J.L.; Minsky, A. Structural studies demonstrating a bacteriophage-like replication cycle of the eukaryote-infecting Paramecium bursaria chlorella virus-1. PLoS Pathog. 2017, 13, e1006562. [CrossRef]

12. Frohns, F.; Käsmann, A.; Kramer, D.; Schäfer, B.; Mehmel, M.; Kang, M.; Van Etten, J.L.; Gazzarrini, S.; Moroni, A.; Thiel, G. Potassium ion channels of chlorella viruses cause rapid depolarization of host cells during infection. J. Virol. 2006, 80, 2437-2444. [CrossRef] [PubMed]

13. Neupärtl, M.; Meyer, C.; Woll, I.; Frohns, F.; Kang, M.; Van Etten, J.L.; Kramer, D.; Hertel, B.; Moroni, A.; Thiel, G. Chlorella viruses evoke a rapid release of $\mathrm{K}^{+}$from host cells during early phase of infection. Virology 2008, 372, 340-348. [CrossRef] [PubMed]

14. Thiel, G.; Moroni, A.; Dunigan, D.; Van Etten, J.L. Initial events associated with virus PBCV-1 infection of Chlorella NC64A. In Progress in Botany; Lüttge, U., Beyschlag, W., Büdel, B., Eds.; Springer: Berlin, Germany, 2010; pp. 169-183.

15. Meints, R.H.; Lee, K.; Van Etten, J.L. Assembly site of the virus PBCV-1 in a Chlorella-like green alga: Ultrastructural studies. Virology 1986, 154, 240-245. [CrossRef]

16. Dunigan, D.D.; Cerny, R.L.; Bauman, A.T.; Roach, J.C.; Lane, L.C.; Agarkova, I.V.; Wulser, K.; Yanai-Balser, G.M.; Gurnon, J.R.; Vitek, J.C.; et al. Paramecium bursaria Chlorella Virus 1 proteome reveals novel architectural and regulatory features of a giant virus. J. Virol. 2012, 86, 8821-8834. [CrossRef]

17. Hiramatsu, S.; Ishihara, M.; Fujie, M.; Usami, S.; Yamada, T. Expression of a chitinase gene and lysis of the host cell wall during Chlorella virus CVK2 infection. Virology 1999, 260, 308-315. [CrossRef]

18. Sun, L.; Adams, B.; Gurnon, J.; Ye, Y.; Van Etten, J.L. Characterization of two chitinase genes and one chitosanase gene encoded by chlorella virus PBCV-1. Virology 1999, 263, 376-387. [CrossRef] [PubMed]

19. Yamada, T.; Hiramatsu, S.; Songsri, P.; Fujie, M. Alternative expression of chitosanase gene produces two different proteins in cells infected with Chlorella virus CVK2. Virology 1997, 230, 361-368. [CrossRef]

20. Sun, L.; Gurnon, J.R.; Adams, B.J.; Graves, M.V.; Van Etten, J.L. Characterization of a $\beta$-1,3-glucanase encoded by chlorella virus PBCV-1. Virology 2000, 276, 27-36. [CrossRef]

21. Ogura, K.; Yamasaki, M.; Yamada, T.; Mikami, B.; Hahimoto, W.; Murata, K. Crystal structure of family 14 polysaccharide lyase with pH-dependent modes of action. J. Biol. Chem. 2009, 284, 35572-35579. [CrossRef]

22. Sugimoto, I.; Onimatsu, H.; Fujie, M.; Usami, S.; Yamada, T. vAL-1, a novel polysaccharide lyase encoded by chlorovirus CVK2. FEBS Lett. 2004, 559, 51-56. [CrossRef]

23. Van Etten, J.L.; Agarkova, I.; Dunigan, D.D.; Tonetti, M.; De Castro, C.; Duncan, G.A. Chloroviruses have a sweet tooth. Viruses 2017, 9, 88. [CrossRef]

24. Meints, R.H.; Burbank, D.E.; Van Etten, J.L.; Lamport, D.T. Properties of the chlorella receptor for the virus PBCV-1. Virology 1988, 164, 15-21. [CrossRef]

25. Agarkova, I.; Hertel, B.; Zhang, X.; Lane, L.; Tchourbanov, A.; Dunigan, D.D.; Thiel, G.; Rossmann, M.G.; Van Etten, J.L. Dynamic attachment of Chlorovirus PBCV-1 to Chlorella variabilis. Virology 2014, 466-467, 95-102. [CrossRef] [PubMed]

26. Van Etten, J.L.; Burbank, D.E.; Kuczmarski, D.; Meints, R.H. Virus infection of culturable chlorella-like algae and dlevelopment of a plaque assay. Science 1983, 219, 994-996. [CrossRef] [PubMed]

27. Reisser, W.; Becker, B.; Klein, T. Studies on ultrastructure and host range of a Chlorella attacking virus. Protoplasma 1986, 135, 162-165. [CrossRef]

28. Agarkova, I.V.; Dunigan, D.D.; Van Etten, J.L. Virion-associated restriction endonucleases of chloroviruses. J. Virol. 2006, 80, 8114-8123. [CrossRef] [PubMed] 
29. Van Etten, J.L.; Burbank, D.E.; Xia, Y.; Meints, R.H. Growth cycle of a virus, PBCV- 1, that infects chlorella-like algae. Virology 1983, 126, 117-125. [CrossRef]

30. Kennedy, J.E. Purification and characterization of a lytic enzyme from viral infection of Chlorella-like green algae. Masters's Thesis, University of Nebraska, Lincoln, Nebraska, 1987.

31. Milrot, E.; Mutsafi, Y.; Fridmann-Sirkis, Y.; Shimoni, E.; Rechav, K.; Gurnon, J.R.; Van Etten, J.L.; Minsky, A. Virus-host interactions: Insights from the replication cycle of the large Paramecium bursaria chlorella virus. Cell. Microbiol. 2016, 18, 3-16. [CrossRef] [PubMed]

32. Skrdla, M.P.; Burbank, D.E.; Xia, Y.; Meints, R.H.; Van Etten, J.L. Structural proteins and lipids in a virus, PBCV-1, which replicates in a Chlorella-like alga. Virology 1984, 135, 308-315. [CrossRef]

33. Guindon, S.; Dufayard, J.-F.; Lefort, V.; Anisimova, M.; Hordijk, W.; Gascuel, O. New algorithms and methods to estimate Maximum-Likelihood phylogenies: Assessing the performance of PhyML 3.0. Syst. Biol. 2010, 59, 307-321. [CrossRef]

34. Altschul, S.F.; Gish, W.; Miller, W.; Myers, E.W.; Lipman, D.J. Basic local alignment search tool. J. Mol. Biol. 1990, 215, 403-410. [CrossRef]

35. UniProt, C. UniProt: A worldwide hub of protein knowledge. Nucleic Acids Res. 2019, 47, D506-D515.

36. Kelley, L.A.; Mezulis, S.; Yates, C.M.; Wass, M.N.; Sternberg, M.J.E. The Phyre2 web portal for protein modeling, prediction and analysis. Nat. Protoc. 2015, 10, 845-858. [CrossRef] [PubMed]

37. Humphrey, W.; Dalke, A.; Schulten, K. VMD: Visual molecular dynamics. J. Mol. Graph. 1996, 14, 33-38. [CrossRef]

38. Sugimoto, I.; Hiramatsu, S.; Murakami, D.; Fujie, M.; Usami, S.; Yamada, T. Algal-lytic activities encoded by chlorella virus CVK2. Virology 2000, 277, 119-126. [CrossRef] [PubMed]

39. Mitchell, A.; Chang, H.-Y.; Daugherty, L.; Fraser, M.; Hunter, S.; Lopez, R.; McAnulla, C.; McMenamin, C.; Nuka, G.; Pesseat, S.; et al. The InterPro protein families database: The classification resource after 15 years. Nucleic Acids Res. 2015, 43, D213-D221. [CrossRef]

40. Imam, S.H.; Buchanan, M.J.; Shin, H.C.; Snell, W.J. The Chlamydomonas cell wall: Characterization of the wall framework. J. Cell Biol. 1985, 101, 1599-1607. [CrossRef]

41. Yamada, T.; Sakaguchi, K. Comparative studies on Chlorella cell walls: Induction of protoplast formation. Arch. Microbiol. 1982, 132, 10-13. [CrossRef] 